\title{
Foreign Direct Investment and Economic Growth in BRICS Economies: A Panel Data Analysis
}

\author{
Gaurav Agrawal
}

\begin{abstract}
The research paper is an attempt to examine the relationship between foreign direct investment (FDI) and economic growth in the five BRICS economies namely, Brazil, Russia, India, China and South Africa over the period 1989-2012. The empirical methodology cointegration and causality analysis at panel level is applied. The results confirm that foreign direct investment and economic growth are cointegrated at the panel level, indicating the presence of long run equilibrium relationship between them. Results from causality tests indicate that there is long run causality running from foreign direct investment to economic growth in these economies. It is thus important that policymakers to remove obstacles to FDI inflows and improve the respective absorptive capacity in order to reap maximum positive growth effects.
\end{abstract}

Index Terms-BRICS, causality, cointegration, FDI, panel data.

\section{INTRODUCTION}

The importance of foreign direct investment (FDI) in developing economies like India has been viewed over the years as a significant factor contributing to economic growth and development. It contributes towards the increasing integration of economies and internationalization of around the world simulated by financial flows, trade technology and resources. In the global perspective, foreign FDI is sensitive to the economic variables and policies of an economy. It positively affects an economy and in most of the cases is observed to be one of the principal factors contributing to economic growth and development. Countries have been actively seeking FDI over the years in view of the expected favorable effect on income generation from capital inflows, advanced technology, source of employment generation and management skills [1]-[3].

Traditionally, FDI promotion policies focused primarily on quantity, i.e. on maximizing inward investment flows. The quantitative approach emphasizes capital accumulation and employment generation. Neoclassical economics viewed the benefits of FDI primarily in terms of a stable source of foreign financing within the balance of payments.

Globalisation advancing in the last decades especially with the improvement of theinformation technology and communication help so much in flows of factors of production over the globe. This process is better for all since all capital, technology and labor will be used more efficiently as long as the borders of the countries are open. MNCs make

Manuscript received October 13, 2013; revised December 15, 2013.

Gaurav Agrawal is with the ABV - Indian Institute of Information Technology \& Management, India (e-mail: drgauravagrawal@gmail.com). use of more and better information to decide on which country of the globe to invest. International investment does not necessarily flow from developed to developing countries. Less advanced sectors in developed countries constitute very profitable opportunities to the MNC situated at the frontier of Research and Development (R\&D). Many MNCs find huge markets and profit opportunities in the slightly less advanced sectors of the developed countries.

A growing strand of the literature attributes the growth impact of FDI depends on the characteristics of the host country. It is argued that the host countries' capacity to absorb FDI productively is linked to their GDP per capita. Host countries with a better endowment of human capital are supposed to benefit more from FDI-induced technology transfers. Openness to trade is also considered important as foreign investors are said to increasingly pursue strategies which require unrestricted trade of intermediate goods at all stages of the production process.

Besides, MNCs specialized in certain high-tech products that are originated in developing countries find opportunities to invest at the developing countries. Attracting FDI and capturing the associated benefits for the domestic economy is associated with effective government intervention. Strategic FDI policies interventions affecting the dynamic pattern of national comparative advantages are required in order to avoid the risk of a low-skill, low-income trap.

UNCTAD estimates that FDI flows will rise moderately in 2012 , to around US\$1.6 trillion. However, the fragility of the world economy, the uncertainties surrounding the future of the euro and rising financial market turbulence, will have an impact on FDI flows in 2012. Hence, due to the global and national interest on every aspect of FDI these days with a focus on the overall development of an economy, it is definitely going to be one of the important and most talked about topic in the upcoming years.

Even though there are a large number of studies examining the relationship between FDI and economic growth at different scales/levels, the results of these studies are not able to clarify the relationship between FDI and economic growth. Commonly accepted, the main effect of FDI on host country economy is that FDI increases productivity through transfer of knowledge, resources, managerial expertises to host market directly or indirectly (in the form of spillovers), resulting in higher economic growth. [4], [5]

With the integration of international capital markets, global FDI flows grew strongly in the 1990s, at a much quicker rate than world economic growth. Recorded global FDI inflows grew by an average of 13 percent a year during 1990-1997. Remarkably, these inflows increased by an average of nearly 50 percent a year during 1998-2000, peaking at a record of $\$ 1.5$ trillion in 2000 , mainly driven by 
large cross-border mergers and acquisitions. After years of growth, global flows of FDI dropped with two consecutive declines to $\$ 824$ billion in 2001 and $\$ 651$ billion in 2002, until remaining stagnant in 2003 at $\$ 653$ billion and picking up again in 2004. FDI flows continued to rise in 2007: at $\$ 1,979$ billion - a new record level surpassing the 2000 figure [6]. The current financial and credit crisis, which began in late 2007, had a dampening impact on the world economies as well as FDI. As a result, FDI flows declined $14 \%$ in 2008 to $\$ 1,697$ billion, and are expected to fall further to $\$ 900-\$ 1,200$ billion in 2009 . Hence, the objective of the current study is to empirically investigate the relationship between FDI and economic growth in the BRICS economies. The study contributes to the existing pool of literature on FDI and Economic Growth Nexus by investigating these set of economies that are attracting huge amount of foreign direct investments during the last few decades. [7]-[10].

\section{LITERATURE REVIEW}

Worldwide FDI represents a major source of funding for capital intensive projects. Developing countries like India have made significant strides as Asia- Pacific's most competitive host for foreign capital. FDI increases capital accumulation in the receiving country by introducing new inputs and technologies [11], [12]. FDI exerts an ambiguous effect on growth [13]. His work further states that FDI in the primary sector, however, tend to have a negative effect on growth, while investment in manufacturing a positive one. Countries with better financial systems and financial market regulations can exploit FDI more efficiently and achieve a higher growth rate [14], [15].

Recently, the FDI inward policy regimes of most countries around the world, both developed and developing, have taken on a liberal framework. The liberalization of core FDI policies consists of reducing barriers for inward FDI, strengthening standards of treatment for foreign investors and ensuring the proper functioning of markets and a level playing field for all investors. Ironically, with policy regimes becoming increasingly open and similar, many countries have found that they need to make further efforts to attract FDI in such a competitive climate; FDI is now recognized as one of the most important sources of much needed capital and managerial, technical and marketing know-how not only in the manufacturing industry, but also in services and the resource based industry. Moreover, world-wide liberalization convergence increases the locational choice for FDI.

Developing countries can attract more FDI with high economic growth rate and investment friendly policies [16]. Hence, one can observe that FDI inflows are attached towards an economy or to economy having high economic growth rate, on the other hand FDI inflows are also instrumental in increasing the growth rate in an economy. This theoretical implication indicates a bi-directional relationship between FDI inflows and economic growth rate. A positive association between FDI and economic growth provided that that the host country should have an attained level of development that helps it reap the benefits of higher productivity [17]. However there also exist contradicting theories that predict FDI in the presence of pre-existing trade, price, financial and other distortions will hurt resource allocation and slow growth.

The consensus in the literature seems to be that FDI increases growth through productivity and efficiency gains by local firms. However, the empirical evidence is not unanimous. The above earlier findings give the evidence that the nexus between foreign direct investment and economic growth is far from straightforward [18]. It varies from country to country and even within a country with different time periods.

\section{Methodology}

In order to analyze the FDI- led- growth hypothesis will be performed in three steps: (1) to test for stationarity or the order of integration; (2) test for cointegration; and (3) test for direction of causality. These three tests were conducted at panel level. The detail descriptions of these tests are as follows:

\section{A. Panel Unit Root Test}

The traditional Augmented Dickey Fuller [19] and Phillips and Perron unit root test is usually used to check the stationarity of time series variables. But the limitation of this technique is that it has a problem of low power in rejecting the null hypothesis of stationarity of the time series, particularly for small size of data. The literature suggests that panel unit root test has higher power than the unit root test based on univariate time series. A number of such tests are available in the literature. For the panel data Levin-Lin (LLC) Tests [20] and Im-Pesaran-Shin (IPS) Test [21] has been identified for the current study. In principle, the IPS test also can be used in association with any parametric unit-root test, as long as the panel is balanced and all the t-statistcs for the unit-root in every crosssection are identically distributed so that they will have the same variance and mean. Then the Central Limit Theorem (CLT) can be applied. Although the IPS test requires a balanced panel, it is the test most often used in practice because it is simple and easy to use.

\section{B. Panel Data Cointegration Analysis}

Cointegration is a statistical property of time series variables. Two or more time series are cointegrated if they share a common stochastic drift.

If two or more series are individually integrated (in the time series sense) but some linear combination of them has a lower order of integration, then the series are said to be cointegrated. A common example is where the individual series are first-order integrated (I(1)) but some (cointegrating) vector of coefficients exists to form a stationary linear combination of them. For instance, a stock market index and the price of its associated futures contract move through time, each roughly following a random walk. Testing the hypothesis that there is a statistically significant connection between the futures price and the spot price could now be done by testing for the existence of a cointegrated combination of the two series. (If such a combination has a low order of integration - in particular if it is $\mathrm{I}(0)$, this can signify an equilibrium relationship between the original series, which are said to be cointegrated.) 
Pooled time series data, much like uni-variate time series data, tend to exhibit a time trend and are therefore non-stationary; i.e., the variables in question have means, variances, and covariances that are not time invariant.

Engle and Granger argue that the direct application of OLS (Ordinary Least Square) or GLS (Generalized Least Square) to non-stationary data produces regressions that are misspecified or 10 spurious in nature. The Panel cointegration technique addresses this issue by allowing one to pool information regarding common long-run relationships between a set of variables from individual members of a panel.

The Panel cointegration technique addresses this issue by allowing one to pool information regarding common long-run relationships between a set of variables from individual members of a panel. Pedroni [22] refers to seven different statistics for testing unit roots in the residuals of the postulated long-run relationship. Of these seven statistics, the first four are referred to as panel cointegration statistics; the last three are known as group mean panel cointegration statistics.

\section{Panel Data Causality Analysis}

The study investigates the causal relationship between FDI and economic growth both at individual level (using pair-wise granger causality analysis) and at panel level using VEC Granger Causality/Block Exogeneity Wald Test.

\section{Result ANALysis}

Table I and Table II represents the test of the stationarity on the data series at panel level. Stationarity check of any time series data is one of the most important requirements before analysis of co-integration and causality. The results indicate that all the time series variables that used in the study have unit roots. The estimated statistics cannot reject the null hypothesis of non-stationarity at 5\% level of significance. However, the variables are found to be stationary at the first difference level, as the null hypothesis of non-stationarity is rejected at $5 \%$ level of significance. This indicate that the variables are integrated of order one i.e. I (1).

TABLE I: VARIABLES SELECTED FOR ANALYSIS AND RESPECTIVE DATA SOURCE

\begin{tabular}{|c|l|l|l|}
\hline & Variable & Proxy used & Source of Data \\
\hline 1. & $\begin{array}{l}\text { Foreign Direct } \\
\text { Investment } \\
(\text { FDI })\end{array}$ & $\begin{array}{l}\text { Amount of } \\
\text { FDI inflows }\end{array}$ & $\begin{array}{l}\text { World Bank's World } \\
\text { Development } \\
\text { Indicator Database }\end{array}$ \\
\hline 2. & $\begin{array}{l}\text { Economic } \\
\text { Growth }\end{array}$ & $\begin{array}{l}\text { Gross } \\
\text { Domestic } \\
\text { Product }\end{array}$ & $\begin{array}{l}\text { World Bank's World } \\
\text { Development } \\
\text { Indicator Database }\end{array}$ \\
\hline
\end{tabular}

After confirming the existence of unit roots for all the data series considered for the study, the next step involves checking the possibility of existence of long run relationship between FDI, exports and economic growth. Table III reports the results of the Pedroni's test respectively. The results of Pedronis Test indicate existence of long run cointegration relationship between economic growth and FDI on the panel of BRICS economies selected for the study. It is observed in the test results that 5 out of 7 of Pedroni's statistics significantly reject the null of no cointegration. This implies existence of a long run co-movement of FDI and Economic Growth. This further indicates that there is possibility of causality between FDI and economic growth. Table IV suggests bidirectional causality between FDI and economic growth is observed between the economies selected for the study pointing towards a feedback between these variables.

TABLE II: PANEL UNIT ROOT TEST

\begin{tabular}{|c|c|c|c|}
\hline & \multicolumn{3}{|l|}{ FDI } \\
\hline & Level & $\begin{array}{l}\text { First } \\
\text { Difference }\end{array}$ & \multirow[t]{2}{*}{$\begin{array}{l}\text { Order of } \\
\text { Integration }\end{array}$} \\
\hline & Statistics & Statistics & \\
\hline Levin, Lin \& Chu (LLC) & 2.72146 & $-4.88992^{*}$ & I (1) \\
\hline $\begin{array}{l}\text { Im, Pesaran and Shin } \\
\text { W-Stat (IPS) }\end{array}$ & 3.08118 & $-4.53969 *$ & I (1) \\
\hline ADF - Fisher Chi-square & 0.86091 & $38.6661^{*}$ & I (1) \\
\hline \multirow[t]{4}{*}{ PP - Fisher Chi-square } & 0.47063 & $43.9521 *$ & I (1) \\
\hline & \multicolumn{3}{|l|}{ GDP } \\
\hline & Level & $\begin{array}{l}\text { First } \\
\text { Difference }\end{array}$ & \multirow[t]{2}{*}{$\begin{array}{l}\text { Order of } \\
\text { Integration }\end{array}$} \\
\hline & Statistics & Statistics & \\
\hline Levin, Lin \& Chu (LLC) & 8.52272 & -4.22523 & I (1) \\
\hline $\begin{array}{l}\text { Im, Pesaran and Shin } \\
\text { W-Stat (IPS) }\end{array}$ & 8.99349 & -2.45890 & I (1) \\
\hline ADF - Fisher Chi-square & 0.00199 & 21.1162 & I (1) \\
\hline PP - Fisher Chi-square & 0.00557 & 19.7856 & I (1) \\
\hline \multicolumn{4}{|c|}{$\begin{array}{l}\text { Note: FDI = Foreign Direct Investment, GDP= Economic Growth } \\
\text { (Gross Domestic Product); No. of Cross-sections }=6 \\
\text { *indicates significant and } 1 \% \text { level of significance }\end{array}$} \\
\hline
\end{tabular}

TABLE III: PEDRONI'S PANEL COINTEGRATION TEST RESULTS

\begin{tabular}{|l|l|l|}
\hline & Statistics & Probability \\
\hline Panel v-Statistic & 1.341809 & 0.0898 \\
\hline Panel rho-Statistic & $-2.095048^{*}$ & 0.0181 \\
\hline Panel PP-Statistic & $-2.092489^{*}$ & 0.0182 \\
\hline $\begin{array}{l}\text { Panel } \\
\text { ADF-Statistic }\end{array}$ & $-1.964268^{*}$ & 0.0247 \\
\hline $\begin{array}{l}\text { Group } \\
\text { rho-Statistic }\end{array}$ & -0.261950 & 0.3967 \\
\hline Group PP-Statistic & $-1.939658^{*}$ & 0.0202 \\
\hline $\begin{array}{l}\text { Group } \\
\text { ADF-Statistic }\end{array}$ & $-1.761847^{*}$ & 0.0300 \\
\hline \multicolumn{2}{|l}{} \\
\hline \multicolumn{2}{|l|}{ Note: *indicates statistical significance at 5\% level. } \\
\hline
\end{tabular}

TABLE IV: VEC GRANGER CAUSALITY/BLOCK EXOGENEITY WALD TESTS

\begin{tabular}{|c|c|c|c|c|}
\hline \multirow[b]{2}{*}{$\begin{array}{l}\text { Dependent } \\
\text { Variable }\end{array}$} & \multicolumn{2}{|c|}{$\begin{array}{l}\text { D(GDP) } \\
\text { (excluded variable) }\end{array}$} & \multicolumn{2}{|c|}{$\begin{array}{l}\text { D(FDI) } \\
\text { (excluded variable) }\end{array}$} \\
\hline & $\begin{array}{l}\text { Chi-sq } \\
\text { Statistics }\end{array}$ & Probability & $\begin{array}{l}\text { Chi-sq } \\
\text { Statistics }\end{array}$ & Probability \\
\hline D(FDI) & 115.7938 & $0.0000^{*}$ & - & - \\
\hline D(GDP) & - & - & 44.08127 & $0.0000^{*}$ \\
\hline \multicolumn{5}{|c|}{$\begin{array}{l}\text { where, GPD = Gross Domestic Product (Economic Growth) } \\
\text { FDI = Foreign Direct Investment } \\
D(.): \text { First difference of the variable mentioned in parentheses. } \\
\text { Degree of freedom }=2 \\
\text { Note: * indicate statistical significance at } 5 \% \text { level } \\
* * \text { indicate statistical significance at } 10 \% \text { level }\end{array}$} \\
\hline
\end{tabular}

\section{CONCLUSION}

The study suggests that FDI-economic growth share long run relationships or are integrated in long run at group (panel) level as confirmed through Pedroni's panel cointegration test results.. Further, the Granger causality test at panel level confirmed the presence of bidirectional causality between FDI-economic growths. Thus, the increase noted in the level 
of FDI help in inducing economic growth and development and vice-versa. The study clearly suggest a positive correlation between growth and foreign investments in a bidirectional way. Hence, if economic growth is likely to attract more FDI inflows, then various policies to attract inward FDI could become unnecessary. Therefore, efforts should also be made to encourage the other potential sources of economic development, that would in-turn simulate and enhance foreign investments.

\section{REFERENCES}

[1] N. Crespo and M. P. Fontoura, "Determinant factors of FD spillovers-what do we really know?" World Development, vol. 35, no. 3, pp. 410-425, 2007.

[2] P. Romer, "Idea gaps and object gaps in economic development," Journal of Monetary Economics, vol. 32, no. 3, pp. 543-573, 1994

[3] World Bank, World Development Indicators, Washington, D.C., 2010

[4] J. Westerlund, New Simple Tests for Panel Cointegration, Forthcoming in: Econometrics Reviews, 2005.

[5] J. Westerlund, "A panel CUSUM test of the null of cointegration," Oxford Bulletin of Economics and Statistics, vol. 62, issue 2, pp. 231-262, 2005.

[6] UNCTAD, World Investment Report: Transnational Corporations and the Infrastructure Challenge, New York and Geneva: United Nation, 2008.

[7] United Nations Conference on Trade and Development (UNCTAD) 1999, World Investment Report (WIR).

[8] United Nations Conference on Trade and Development (UNCTAD) 2005, World Investment Report (WIR).

[9] United Nations Conference on Trade and Development (UNCTAD) 2007, World Investment Report (WIR).

[10] UNCTAD, World Investment Report: Transnational Corporations, Agricultural Production and Development, New York and Geneva: United Nation, 2009.

[11] M. Blomstrom, R. Lipsey, and M. Zejan, "What explains developing country growth," NBER Working Paper No. 4132, NBER, Cambridge, MA, 1992.

[12] E. Borensztein, J. D. Gregorio, and J. W. Lee, "How does foreign direct investment affect growth?" Journal of International Economics, vol. 45, pp. $115-35,1998$

[13] L. Alfaro. (2003). Foreign Direct Investment and Growth: Does the Sector Matter? Harvard Business School. [Online]. Available: http://www.people.hbs.edu/lalfaro/fdisectorial.pdf
[14] B. Durham, "Absorptive capacity and the effects of foreign direct investment and equity foreign portfolio investment on economic growth," European Economic Review, vol. 48, no. 2, pp. 285-306, 2004.

[15] N. Hermes and R. Lensink, "Foreign direct investment, financial development and economic growth," The Journal of Development Studies, vol. 40, no. 1, pp. 142-163, 2003.

[16] A. M. Khondoker. (2007). Determinants of foreign direct investment and its impact on economic growth in developing countries. MPRA paper No. 9457. [Online]. Available http//www.mpra.ub.uni-muenchen.de/9457/

[17] D. T. Coe, E. Helpman, and A. W. Hoffmaister, Economic Journal, North-South R\&D Spillovers, vol. 107, pp. 134-149, 1997.

[18] T. B. Vu and I. Noy, "Sectoral analysis of foreign direct investment and growth in the developed countries," Journal of International Financial Markets, Institutions and Money, vol. 19, pp. 402-413, 2009.

[19] D. A. Dickey and W. A. Fuller, "Distribution of the estimators for autoregressive time series with a unit root," Econometrica, vol. 49, pp. 1057-72, 1981.

[20] A. Levin, C. F. Lin, and C. S. J. Chu, "Unit root tests in panel data: asymptotic and finite - sample properties," Journal of Econometrics vol. 1, no. 24, pp. 108, 2002.

[21] K. Im, M. H. Pesaran, and Y. Shin, "Testing for Unit roots in Heterogeneous panels," Journal of Econometrics, vol. 115, no. 1, pp. 53-74, 2003

[22] P. Pedroni, "Critical Values for Cointegration tests in heterogeneous panels with multiple regressors," Oxford Bulletin of Economics and Statistics, vol. 61, pp. 653-670, 1999.

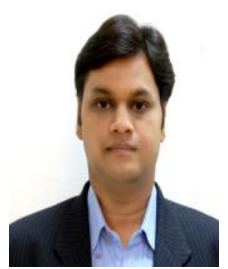

Gaurav Agrawal is working an as associate professor in the ABV - Indian Institute of Information Technology and Management Gwalior (IIITM). He has more than 14 years of experience in research, teaching and industry, to his credit. Prior to joining the ABV - IIITM Gwalior, he was an assistant professor at the Foundation of Organisational Research in Education (FORE) School of Management, New Delhi, Gautam Buddha University (GBU), Greater Noida, and the Bundelkhand University Jhansi. He was also awarded Fellowship of Indian Institute of Advanced Studies (IIAS), Shimla. He began his career with the industry experience as Executive with the Cello Plast Ltd. Mumbai and the Dolphin International Ltd., New Delhi. He has already published many research papers in international refereed journals, national refereed journals and international conference proceedings and also presented research papers in various international and national conferences in USA, UK, Singapore, IIM Ahmadabad, IIM Bangalore etc. 